\title{
Gaura lindheimeri 'Snowstorm': A New Z6 Heat/frost-tolerant Container and Landscaping Perennial
}

\author{
Neil Anderson ${ }^{1,10}$ \\ Department of Horticultural Science, University of Minnesota, 286 Alderman \\ Hall, 1970 Folwell Avenue, St. Paul, MN 55108
}

Lee Klossner ${ }^{2}$ and Neal Eash ${ }^{2}$

Southwest Research and Outreach Center, Lamberton, MN 56162

Vincent Fritz ${ }^{3}$ and Minnie Wang ${ }^{4}$

Southern Research and Outreach Center, Waseca, MN 56093

Stephen Poppe ${ }^{5}$

West Central Research and Outreach Center, Morris, MN 56267

Judith Reith-Rozelle ${ }^{6}$

West Madison Agricultural Research Station, Verona, WI 53593

\section{David Wildung ${ }^{7}$, Shengrui $\mathbf{Y a o}^{2}$, and Patricia Johnson ${ }^{8}$ \\ North Central Research and Outreach Center, Grand Rapids, MN 55744}

\author{
Barbara E. Liedl $\mathbf{9}^{9}$ \\ Gus R. Douglass Institute, Agricultural and Environmental Research Station, \\ West Virginia State University, Institute, WV 25112
}

Additional index words. heat tolerance, drought tolerance, frost tolerant flowers, Onagraceae

Gaura species (Onagraceae) are native to all three North American countries, extending from British Columbia to southern Mexico (Carr et al., 1990). The center of origin and diversity for the genus is Texas with the highest concentration of species (Anderson et al., 2003; Hoch et al., 1993; Praglowski et al., 1988). Gaura are drought/heat-tolerant annuals and perennials with continuous flowering potential (Anderson and Peters, 2001). Likewise, given the wide range of species throughout North America-particularly polyploids - additional adaptive traits such as tolerance of heat and cold tolerance, extremes in soil $\mathrm{pH}$ ranges, and drought are also prevalent in the gaura genome (Anderson et al., 2003).

Gaura lindheimeri Engelm. \& Gray, with the common name wandflower, is a nonrhizomatous herbaceous perennial (USDA Zones 5 to 6 ; Nau, 1999) native to southeastern Texas and southwestern Louisiana. The

Received for publication 2 Apr. 2009. Accepted for publication 3 June 2009.

${ }^{1}$ Associate Professor.

${ }^{2}$ Research Fellow.

${ }^{3}$ Professor.

${ }^{4}$ Research Plot Coordinator.

${ }^{5}$ Scientist.

${ }^{6}$ Assistant Superintendent.

${ }^{7}$ Professor Emeritus.

${ }^{8}$ Non/Exempt Temporary or Casual Scientist.

${ }^{9}$ Associate Research Professor.

${ }^{10}$ To whom reprint requests should be addressed; e-mail ander044@umn.edu. species is diploid $(2 n=2 x=14$; Carr et al., 1990) with a gametophytic self incompatibility system (Peters and Anderson, 2006). Wandflower was first introduced in the 1840 s and remained on the market for $\approx 60$ years (Raven and Gregory, 1972a, 1972b). It returned to the market in 1994 with the introduction of 'Siskiyou Pink', a pink-flowering sport (Pride of Place Plants, 2000). 'Siskiyou Pink' is a sport found at Siskiyou Rare Plant Nursery in Medford, OR (Pride of Place Plants, 2000). A 'Butterflies' series was subsequently developed out of 'Siskiyou Pink' by Howard Bently of Plant Growers Australia: 'Crimson Butterflies', 'Blushing Butterflies', and 'Sunny Butterflies' (Pride of Place Plants, 2000). When grown from seed, $G$. lindheimeri will flower in the first year (Nau, 1999); only one cultivar is seedpropagated ('The Bride'). It increased in popularity with most vegetative producer companies marketing individual cultivars or series in their product offerings. Wandflower was ranked in the top 23 perennial plants during 2001 (Behe et al., 2002).

Two gaura, Gaura lindheimeri and $G$. demareei P.H. Raven \& Gregory, are the only bee-pollinated species with flowers opening in the morning (Raven and Gregory, 1972a, 1972b). All other Gaura species are pollinated by noctuids with flowers opening in the evening. Gaura lindheimeri have spicate racemes of delicate, zygomorphic flowers, which may be frost-tolerant, providing season extenders into the fall for northern gardeners (Anderson and Peters,
2001). If grown as an annual, it will flower from July through October from seed in the first year. Some of the earliest and most popular G. lindheimeri cultivars on the market are 'Siskiyou Pink' (light pink flowers) and 'Whirling Butterflies' (white flowers). The hardiness zones for $G$. lindheimeri are listed as USDA Zone 5 to Zone 6 (Nau, 1999), although many nurseries and garden centers in Zone 3 and Zone 4 continue to sell these cultivars as perennials despite tests that have proved otherwise (Anderson et al., 2001). In 1999, a Gaura breeding program was established at the University of Minnesota to produce winter-hardy forms with the large flower size of $G$. lindheimeri. One winter-hardy species, G. coccinea, grows from Canada (Zone 2) to Mexico (Zone 10) (Anderson et al., 2003) and is being used as a source of winterhardiness (Pietsch and Anderson, 2006; Pietsch et al., 2009). Autotetraploid $G$. lindheimeri have been created (Pietsch and Anderson, 2007) to cross with allotetraploid, Zones 2 to 4 winter-hardy $G$. coccinea. Gaura 'Snowstorm' is the first release from the program.

\section{Origin}

A replicated series of field evaluation tests in 2000 to 2001 were conducted in St. Paul (University of Minnesota, lat. 4458' 58.849" N; USDA Zone 4) and Lino Lakes, MN (Lino Lakes Correctional Facility, lat. $45^{\circ} 9^{\prime} 37^{\prime \prime} \mathrm{N}$; USDA Zone 4) to select $G$. lindheimeri parents for the breeding program. An openpollinated seedling population from Applewood Seed Company (Lot \#AE02129; Arvada, CO) was germinated and seedlings were transplanted into field trials in June 2000 (Anderson and Peters, 2001). Several seedlings survived the winter at the Lino Lakes site. 'Snowstorm' (Minnesota Selection Lino Lakes-01) was selected the following spring (2001) (Fig. 1). Cuttings were rooted from emergent crown shoots to establish stock plants. Subsequent replicated performance and winterhardiness trials were conducted with 'Snowstorm' at several test site locations in Minnesota, Wisconsin, and West Virginia (Table 1).

\section{Description and Performance}

Mature plants grown in St. Paul, MN (lat. $44^{\circ} 58^{\prime} 58.849^{\prime \prime} \mathrm{N}$ ) were evaluated for all descriptive and performance data $(n=5$ replications). 'Snowstorm' gaura has an upright plant habit with intermediate stem strength. Lateral branches achieve a mean \pm SD length of $15.6 \pm 6.4 \mathrm{~cm}$ with an average of $10.2 \pm 1.3$ branches/plant early in the season. Stem coloration is Royal Horticultural Society (RHS) Green 144A (Royal Horticultural Society, 1995). 'Snowstorm' has alternate phyllotaxy and produces $511.3 \pm 11.1$ leaves/ plant with $4.2 \pm 4.5$ leaves/lateral branch. 'Snowstorm' has well-colored, dark green foliage (RHS 144B) and lighter colored venation on its adaxial/abaxial surfaces (RHS $76 \mathrm{~B} / 76 \mathrm{C})$. The upper leaf texture is glaucous, 


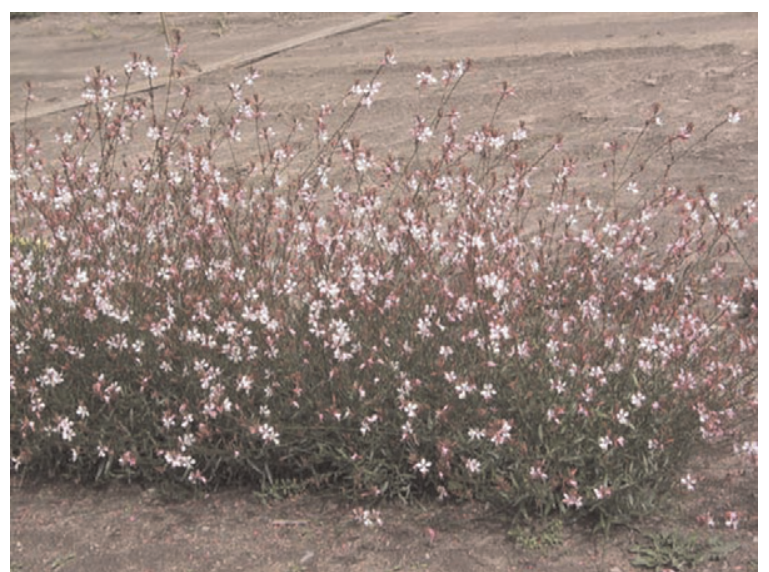

Fig. 1. Flower and plant habit of Gaura lindheimeri 'Snowstorm' grown in Grand Rapids, MN. Photo credit: Neil Anderson.

Table 1. Flowering time and mean percentage of winter survival (mean values for each trial site, 2003 to 2008; $\mathrm{n}=10 \mathrm{reps} / \mathrm{site}$ ) of Gaura lindheimeri MN Selection 'Snowstorm' and comparisons ('Siskiyou Pink', 'Dauphine' for St. Paul site only) for flower, foliage, and plant characteristics grown at various geographic locations, U.S. Department of Agriculture (USDA) plant hardiness zones (http:// www.usna.usda.gov/Hardzone/index.html)/American Horticultural Society (AHS) heat zones (http://www.ahs.org/pdfs/05_heat_map.pdf). ${ }^{z}$

\begin{tabular}{|c|c|c|c|c|c|c|}
\hline \multirow{2}{*}{$\begin{array}{l}\text { Test site } \\
\text { location }\end{array}$} & \multirow[b]{2}{*}{ Latitude } & \multirow[b]{2}{*}{ Longitude } & \multirow{2}{*}{$\begin{array}{l}\text { USDA plant } \\
\text { hardiness/AHS } \\
\text { heat zones }\end{array}$} & \multicolumn{2}{|c|}{ Flowering dates } & \multirow{2}{*}{$\begin{array}{c}\text { Percent } \\
\text { winter } \\
\text { survival }\end{array}$} \\
\hline & & & & Start & Finish & \\
\hline \multicolumn{7}{|l|}{ Snowstorm } \\
\hline Grand Rapids, MN & $47.24739^{\circ} \mathrm{N}$ & $93.54444^{\circ} \mathrm{W}$ & $3 \mathrm{~b} / 3$ & 30 July & 15 Oct. & 0.0 \\
\hline Morris, MN & $45.62820^{\circ} \mathrm{N}$ & $95.88908^{\circ} \mathrm{W}$ & $3 \mathrm{~b} / 4$ & 24 July & 14 Oct. & 0.0 \\
\hline St. Paul, MN & $44.98776^{\circ} \mathrm{N}$ & $93.13700^{\circ} \mathrm{W}$ & $4 \mathrm{a} / 5$ & 10 July & 31 Oct. & 5.0 \\
\hline Lamberton, MN & $44.23111^{\circ} \mathrm{N}$ & $95.26389^{\circ} \mathrm{W}$ & $4 \mathrm{~b} / 5$ & 28 July & 31 Oct. & 0.0 \\
\hline Waseca, MN & $43.90669^{\circ} \mathrm{N}$ & $93.43338^{\circ} \mathrm{W}$ & $4 b / 5$ & 10 Aug. & 11 Nov. & 0.0 \\
\hline W. Madison, WI & $43.09^{\circ} \mathrm{N}$ & $89.37^{\circ} \mathrm{W}$ & $5 \mathrm{a} / 5$ & 26 July & 10 Nov. & 10.0 \\
\hline Institute, WV & $38.1794^{\circ} \mathrm{N}$ & $81.3276^{\circ} \mathrm{W}$ & $6 \mathrm{~b} / 6$ & 30 June & 14 Dec. & 75.0 \\
\hline \multicolumn{7}{|l|}{ Siskiyou Pink } \\
\hline St. Paul & $44.98776^{\circ} \mathrm{N}$ & $93.13700^{\circ} \mathrm{W}$ & $4 \mathrm{a} / 5$ & 18 Aug. & 16 Oct. & 0.0 \\
\hline \multicolumn{7}{|l|}{ Dauphine } \\
\hline St. Paul & $44.98776^{\circ} \mathrm{N}$ & $93.13700^{\circ} \mathrm{W}$ & $4 \mathrm{a} / 5$ & 20 Aug. & 30 Oct. & 0.0 \\
\hline
\end{tabular}

${ }^{2}$ Rooted stem tip cuttings (pinched) were planted at each site in late May (Weeks 21-22; southern sites) to mid-June (Weeks 23-25; northern sites).

whereas the lower surface is glabrous. Leaf apices and bases are acute and cuneate, respectively, with entire leaf margins. Mature leaf dimensions are $28.3 \pm 25.2 \times 5.2 \pm 3.1$ $\mathrm{mm}$ (length $\times$ width). First-year plant growth increases during the season in the garden (field): midseason (late July) 'Snowstorm achieves $50.8 \pm 8.7 \times 33 \pm 7.4 \mathrm{~cm}$ (height $\times$ width) midseason (late July) increasing in size by late season (September) to $99.1 \pm$ $10.8 \times 132.1 \pm 5.6 \mathrm{~cm}$. Containers restrict growth such that late-season (September) growth attains $69.1 \pm 9.3 \times 67.3 \pm 11.6 \mathrm{~cm}$. The well-branched plants make 'Snowstorm' an ideal specimen gaura for landscape purposes-significantly taller than 'Siskiyou Pink' and other dwarf forms. 'Dauphine' has a similar plant growth form and size as 'Snowstorm'.

'Snowstorm' is floriferous with white flowers that will "pink" as the flower petals age or at all stages of petal aging during cool nights of the fall season. Mean flower bud sizes are $6.6 \pm 0.6 \mathrm{~mm}$ (length) $\times 1.5 \pm 0.2$ $\mathrm{mm}$ (diameter). On average, mature 'Snowstorm' possesses $60.2 \pm 20.8$ open flowers/ plant with inflorescence diameters and lengths of $32.2 \pm 1.9 \times 20.7 \pm 0.4 \mathrm{~mm}$, respectively. Floral bracts are $10.6 \pm 0.9 \times$ $1.9 \pm 0.5 \mathrm{~mm}$ (length $\times$ width) and dark pink in color (RHS 54B/64B, adaxial/abaxial surfaces). Flower petal sizes are $15.1 \pm 1.3 \times$ $8.4 \pm 0.4 \mathrm{~mm}$ (length $\times$ width). Flower buds are white RHS 145B followed by opening white flower petals of RHS 57B/66B (adaxial/ abaxial) and mature pink petals exhibiting RHS 76D/76D on both surfaces. Throughout the summer, the numerous white flowers create the appearance of snowflakes and, thus, a snowstorm. Reproductive organ colors range from anthers with RHS 187A and RHS 10A-colored pollen, whereas the style coloration is RHS $150 \mathrm{D}$.

Gaura 'Snowstorm' flowering period in Zone ranges from June to a hard frost (mid- to late October through December), outperforming comparisons such as 'Dauphine' and 'Siskiyou Pink' (Table 1). Flowers are tolerant of light frosts $\left(-1\right.$ to $0{ }^{\circ} \mathrm{C} / 30$ to $32^{\circ} \mathrm{F}$ ); one site reported full recovery of flowering after a heavy frost at $-3.6{ }^{\circ} \mathrm{C}\left(25.6^{\circ} \mathrm{F}\right)$ (data not shown). Floral displays are prolific throughout the growing season in both high summer and low fall day/night temperatures at all locations-midsummer (Fig. 1) and end of season. Thus, 'Snowstorm' is both heat- and cold-tolerant. Heat tolerance and its vigorous growth make 'Snowstorm' ideal for containers and in the landscapes, used as a specimen plant or in highway median plantings.

Because 'Snowstorm' does not produce rhizomes - unlike related G. coccinea and $G$. drummondii (Pietsch et al., 2009), it is an annual bedding plant selection for far northern latitudes (USDA Zones 2 through 4) but an herbaceous perennial in Zone $6+$, depending on location (Table 1). Winter survival reports from the trial sites are: $0 \%$ (Zone 3, Zones 3/4), 0\% to 5\% (Zone 4), 10\% (Zone 5 ), and $75 \%$ (Zone 6) (Table 1). Winter survival within $G$. lindheimeri for a wide range of cultivars and seed populations trialed at the St. Paul, MN, sites is similar $(0 \%$ survival) within Zone 4 (Anderson et al., 2001; Anderson and Peters, 2001).

\section{Culture}

'Snowstorm' is a vegetatively propagated clone using stem tip cuttings. It can be produced commercially for spring bedding plant sales (e.g., for Mother's Day) in 806, 804, 1204, and 1206 trays, larger sized containers, and color pots. Stem tip cuttings root in 1.5 weeks under mist propagation after a treatment with $1000 \mathrm{ppm}$ indole butyric acid in $70 \%$ EtOH (Anderson and Peters, 2002). For stock plant maintenance, short-day photoperiods can delay flowering because this is a facultative long-day plant. Supplemental weekly applications of $300 \mathrm{ppm}$ Ethephon (Florel; Rhone Poulenc Agric. Co., St. Louis, MO) +5 ppm gibberellic acid also aid in delaying bud set. Large containerized plants can be planted directly into landscapes for an "instant" mature plant form. 'Snowstorm' is particularly well adapted for use in highway dividers and as a tall landscape plant.

Full sun exposure is the optimum growing condition for 'Snowstorm'. When grown in partial or complete shade conditions, weak stems may lodge easily in wind/rain storms, stems will be taller, and flowering may not occur. Gaura have deep tap root systems requiring good drainage for stand establishment and performance (Anderson and Peters, 2001).

\section{Availability}

'Snowstorm' was approved for release by the Horticultural Variety Release Committee, Minnesota Agricultural Experiment Station, University of Minnesota in 2007. Rooted or unrooted cuttings of 'Snowstorm' are available to growers (wholesale) in North America from Malmborg's, Inc. (http://www. malmborgsinc.com/), a licensed propagator. Royalty administrations (\$0.035/cutting) are 
assessed at the wholesale level and licenses are administered under the auspices of the Minnesota Nursery Research Corporation. Parties interested in licensing, propagating, and distributing 'Snowstorm' may contact Mr. Jim Stolzenburg at the Minnesota Nursery Research Corporation (jim.stolzenburg@ baileynursery.com).

\section{Literature Cited}

Anderson, N., M. Maguire Lerman, Minneapolis Men's Garden Club, S. Poppe, G. Mesenbring, and L. Wilkes. 2001. 2001 herbaceous perennial trial results. 3 Mar. 2009. <http://www.florifacts. umn.edu/>.

Anderson, N. and W. Peters. 2002. Potted plant production of Gaura lindheimeri. Minnesota Commercial Flower Growers Bulletin 51:7-9.

Anderson, N.O. and W. Peters. 2001. Breeding for winter hardy Gaura. Perennial Plant Quarterly, Spring:45-52.
Anderson, N.O., G. Pietsch, and N. Gomez. 2003. Plant collection and genetic variation in Texas Gaura populations. Perennial Plant Quarterly Spring:28-43.

Behe, B., J.L. Hall-Dennis, and R.M. Walden. 2002. 2001 USDA season sales summary. Ohio Florists Association Bulletin. Mar. 2002.

Carr, B.L., J.V. Crisci, and P.C. Hoch. 1990. A cladistic analysis of the genus Gaura (Onagraceae). Syst. Bot. 15:454-461.

Hoch, P.C., J.V. Crisci, H. Tobe, and P.E. Berry. 1993. A cladistic analysis of the plant family Onagraceae. Syst. Bot. 18:31-47.

Nau, J. 1999. Ball culture guide. 3rd Ed. Ball Publishing, Batavia, IL.

Peters, W.L. and N.O. Anderson. 2006. Statistical discrimination between pollen tube growth and seed set in establishing self incompatibility in Gaura lindheimeri. Euphytica 149:237-250.

Pietsch, G. and N. Anderson. 2006. Development of cold tolerant Gaura lindheimeri: I. Characterization of G. coccinea. MNLA Foundation Bulletin 2:22-24.
Pietsch, G. and N.O. Anderson. 2007. Epigenetic variation in tissue cultured Gaura lindheimeri. Plant Cell Tissue Organ Cult. 89:91-103.

Pietsch, G.M., N.O. Anderson, and P.H. Li. 2009 Cold tolerance and short day acclimation in perennial Gaura coccinea and G. drummondii. Sci. Hort. 120:418-425.

Praglowski, J., J.W. Nowicke, P.H. Raven, J.J. Skvarla, and P.C. Hoch. 1988. Onagraceae Juss. Onagreae R. Raimann P.P. Lopezieae Spach. World Pollen \& Spore Flora 16:1-34.

Pride of Place Plants. 2000. Catalog. 1 Apr. 2009. $<$ http://prideofplaceplants.com/catalog.htm $>$. Sidney, British Columbia, Canada.

Raven, P.H. and D.P. Gregory. 1972a. A revision of the genus Gaura (Onagraceae). Memoirs of the Torrey Botanical Club, (Dec.) 1:1-96. Seeman Printers, Durham, NC.

Raven, P.H. and D.P. Gregory. 1972b. Observations of meiotic chromosomes in Gaura (Onagraceae). Brittonia 24:71-86.

Royal Horticultural Society. 1995. RHS colour chart. 3rd Ed. The Society, London, UK. 